\title{
Problems of Introduction of Innovative Technologies and Modern Equipment in the Fishing Industry
}

\author{
Olimov Lutfiddin Omanovich, Yusupov Abdurashid Khamidillaevich*, Alijanov Donyorbek \\ Dilshadovich \\ Andijan Machine Building Institute, Uzbekistan.
}

*Corresponding Author: A.Kh. Yusupov, Andijan Machine Building Institute, Uzbekistan.

\begin{abstract}
For the first time, a fishing lighting device was proposed to strengthen the fishery food reserve. The device is protected from external influences, which provides fish with natural nutrients and volatile insects with the help of modern energy-saving light bulbs.
\end{abstract}

Keywords: light bulbs, transformers, high voltage, conductors, insects, fisheries.

\section{INTRODUCTION}

It is well known that the fish industry is one of the important strategic directions of ensuring world food security. The development of this area depends on the fish food reserve. There are various ways in the world to strengthen the fishery food reserve and are widely used in practice. In particular, natural and man-made reservoirs use natural, complementary and standardized nutrients to feed fish. Natural nutrients are more important than other types of feed as they prevent fish from infecting various diseases. Natural nutrients with a nutritional value of 8-10 include naturally occurring water-bearing plants, bacteria, detritus, benthos, insects, aquatic animals and others [1, 2, 3]. The complementary feed for feed additives is 5-6, which is manufactured by special industrial method. Normalized feeds are extremely nutritious, with a feed rate of 1.5-2.0 and made at special plants. Fish fed with it are highly productive but extremely expensive. However, feeding of fish by such methods is not without a number of general disadvantages. For example, specific industries or factories that produce complementary feed or standardized feed require additional labor or technology to feed fish. This will lead to an increase in the natural food reserve of the fishery sector and an increase in the cost of fish feeding.

There are also ways to feed fish with insects, worms or larvae of natural feeding. This is an unconventional method that has been used in ancient times for the feeding of fish of different kinds, dead animals or other types of yeast. It is important to note that this is not mentioned in the literature as a separate method. According to it, animal or other types of yeast were hung over the pond for a while, and various birds and insects were fed with animal flesh or other yeast. The worms or larvae that emerged during this process were fed to the fish as they fell into the pond. The main disadvantage of this method is the spread of various diseases to the environment and the watershed.

Taking into account the nature and disadvantages of the methods considered, one of the urgent problems is to ensure food security in the world through the creation and introduction of environmentally friendly, modern innovative technologies and equipment to increase the natural food reserve of the fishing industry. In this work, we will explain the essence and working principle of the fishing equipment [4], which was first developed on the basis of physical and technical solutions.

Figure 1 shows the electrical circuit of the unit, which consists of a circuit breaker transistor [5, 6, 7] with high-voltage transformer $[8,9,10]$ switches, optical radiation source and conductors. 


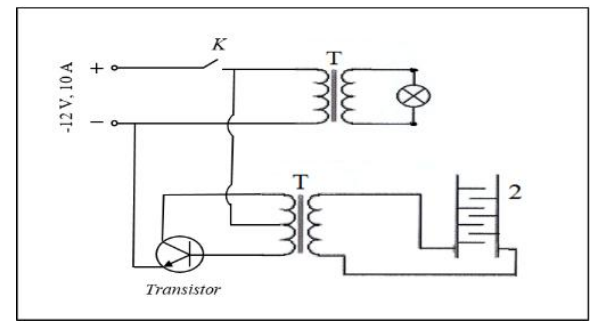

Figure1. Electrical circuit diagram of the device.

\section{DEVICE SPECIFICATIONS}

The transistor provides a constant voltage of 12 volts to the transformer. The secondary circuit of the transformer generates a high voltage of $\sim 3000$ volts which is transmitted to a string net. The range of exposure of the device to insects ranges from a 200 to $500 \mathrm{~m}$ radius. Power supply (running time) 1 day.

\section{RESULTS OF THE EXPERIMENT}

Figure 2 shows a simplified scheme of this device. According to the function and structure the device consists of a horizontal base, protection against various precipitation, protective energy sources of optical radiation, high-voltage net and electrical circuits. The base of the device consists of 4 stencils with glass tubes (1). A high-voltage appliance for exterminating insects (2) is mounted on the glass surface, with an energy source of energy-saving optical radiation (3). There is a hood (4) on the top of the device that protects it from precipitation. The hood is fastened to both ends of the base. Electrical circuit elements (5) are located inside the cap. They consist of low-voltage transformers, power converters, switches and conductors. The battery or a voltage of 220 volts at $50 \mathrm{~Hz}$ can be used as a source of energy. It will be selected depending on the operating conditions of the device.

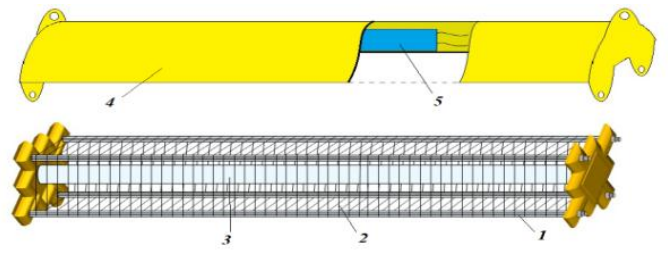

Figure2. Modern energy-saving fishing lighting equipment

The device has the following operating principles: The protective hood and the bottom of the hood are yellow, and the radiation of the light from the source of the optical radiation (illumination) provides a wide range of reflection due to the color hood and the water-back interference phenomenon. This makes it more attractive to insects around the pond. The light source is surrounded by a high-voltage net. Its mission is to kill insects that reach the device in light of the light. The range of high-voltage net cells is 5-8 millimeters. Insects that seek for light move between high-voltage cells. In this process, insects die in high-voltage net cells and fall into the pond. This provides the natural feed, i.e. insects for fish.

It was found that the efficiency of the device varies from late evening to dawn in Uzbekistan. The following table lists the operating periods of the device during the year.

Period of device operation by season

\begin{tabular}{|c|c|c|c|}
\hline \multicolumn{3}{|c|}{ Seasons } \\
\hline Winter & Spring & Summer & Autumn \\
\hline $16^{\underline{3}}-6^{0 \underline{0}}$ & $17^{\underline{00}}-3 \underline{\underline{30}}$ & $17 \underline{00}-3 \underline{0} \underline{0}-4 \underline{\underline{0}}$ \\
\hline
\end{tabular}

Such improvements to the device have not been reported in the literature to date.

Being offered for the first time this device has no analogue in the world. It differs from other methods with the usefulness and convenience to expand its natural feed (fly insects) of the fish industry with modern energy efficient lighting.

\section{CONCLUSiON}

It is noteworthy that the proposed facility will allow the fish industry to accelerate the development of the fish industry, particularly to create a complementary source of feed for fish autonomously without 
human factor based on physical and technical solutions in addition to the efficient use of available resources.

\section{REFERENCES}

[1] D.Niyozov. Baliq-bitmas boylik. Tadbirkorlar uchun qo'llanma. "Dizayn-Press" MCHJ nashriyoti. Toshkent, 2013 y. 192 b.

[2] D.Xolmirzayev, P.S. Haqberdiyev, D.R. Shohimardonov, E.S. Shaptaqov. Baliqchilik asoslari. Toshkent, «Ilm ziyo», 2016, 248 b.

[3] M.N.Ilin. Akvariumnoe ribovodstvo. Moskva, Izdatelstvo Moskovskogo universiteta. 1977. http://www.aqua-art.spb.ru.

[4] UZ FAP 2019 0121. Baliqchilik uchun yoritish qurilmasi. L.O. Olimov, A.X. Yusupov, F.L. Omonboev, E.E. Yusupov.

[5] U.Tittse, K.Shenk. poluprovodnikovaya sxematexnika. 12-e izd. Tom I: Per. s. Nem-M.: DMK 52 b, 308 b.

[6] N.V.Burbaeva, T.S.Dneprovskaya. Osnovi poluprovodnikovoy elektroniki. I.P. Fizmatlit. Moskva 2012. 92 b.

[7] A.A.Shuka. Elektronika 2-e izdanie. I.P. BXV-Peterburg. Sank-Peterburg 2008. 203 b.

[8] A.I.Voldek, V.V.Popov Elektricheskie mashini. Vvedenie v elektromexaniku. Mashini postoyannogo toka i transformatori. Piter, 2007. 242-302 b

[9] G.F.Bistritskiy, B.I.Kudrin. Elektrosnabjenie. Silovie transformatori. Moskva «Yurat» 2018. 13 b, 18 b.

[10] I.P.Kopilov. Elektricheskie mashini. Moskva «Yurat» 2012. 206 b.

Citation: Yusupov Abdurashid Khamidillaevich, et.al., (2019). " Problems of Introduction of Innovative Technologies and Modern Equipment in the Fishing Industry". International Journal of Research Studies in Electrical and Electronics Engineering (IJRSEEE), 5(4), pp 23-25. DOI: http://dx.doi. org/10.20431/24549436.0504005

Copyright: () 2019 Authors. This is an open-access article distributed under the terms of the Creative Commons Attribution License, which permits unrestricted use, distribution, and reproduction in any medium, provided the original author and source are credited. 